Asian-Australasian Journal of

Food Safety and Security

ISSN 2523-1073 (Print) 2523-2983(Online)

https://www.ebupress.com/journal/aajfss/

\title{
Article \\ Heavy metal contamination and antibiotic residues in poultry feed and meat in Bangladesh
}

Md Mahbubul Alam ${ }^{1}$, Dwijendra Lal Mallick ${ }^{1}$, Md Murshidul Ahsan ${ }^{1}$, AHM Taslima Akhter ${ }^{2}$, Eftesum ${ }^{1}$, Farhana Rahman ${ }^{3}$, S. M. Lutful Kabir ${ }^{4}$ and A Atiq Rahman ${ }^{1}$

${ }^{1}$ Bangladesh Centre for Advanced Studies (BCAS), House \#10, Road \#16A, Gulshan-1, Dhaka-1212, Bangladesh

${ }^{2}$ Promoting Knowledge for Accountable Systems (PROKAS), British Council, Flat A2, House 12, Road 7, Baridhara, Dhaka 1212, Bangladesh

${ }^{3}$ Bangladesh Forest Department, Agargaon, Sher-e-Bangla Nagar, Dhaka-1207, Bangladesh

${ }^{4}$ Department of Microbiology and Hygiene, Bangladesh Agricultural University, Mymensingh-2202, Bangladesh

*Corresponding author: Dr. Md. Mahbubul Alam, Senior Programme Management Specialist, Bangladesh Centre for Advanced Studies (BCAS), House \# 10, Road \# 16A, Gulshan-1, Dhaka-1212, Bangladesh. Phone: +8801716367796; E-mail: mahbub.wtb@gmail.com

Received: 02 September 2021/Accepted: 02 November 2021/ Published: 30 November 2021

Copyright (C) $2021 \mathrm{Md}$ Mahbubul Alam et al. This is an open access article distributed under the Creative Commons Attribution 4.0 International License (https://creativecommons.org/licenses/by/4.0/), which permits unrestricted use, distribution, and reproduction in any medium, provided the original work is properly cited.

\begin{abstract}
Presence of harmful contaminants and residues in poultry feed and meat have serious public health consequence. This study was carried out to identify and quantify antibiotic residues, heavy metals and toxins in poultry feed and meat in the two selected poultry production belts of Bangladesh. A total of 94 broiler feed samples and 60 broiler meat samples were collected and tested by Thin Layer Chromatography (TLC), High Performance Liquid Chromatography (HPLC) and Enzyme-linked Immunosorbent Assay (ELISA) for identification and quantification of the parameters. Antibiotic residues were detected in $18.89 \%$ of the feed samples, whereas, there were no toxin (Aflatoxin) positive samples. Among the antibiotic positive samples, Oxytetracycline (OTC) was found predominant and detected in $12.22 \%$ cases. The mean concentrations of Cadmium (Cd), Lead ( $\mathrm{Pb}$ ), Chromium (Cr) were found as $0.04 \mathrm{mg} / \mathrm{kg}, 1.28 \mathrm{mg} / \mathrm{kg}$ and $2.55 \mathrm{mg} / \mathrm{kg}$ respectively in feed samples. In the case of meat samples, the mean concentration of OTC, Ciprofloxacin (CIP), and Tetracycline (TCL) residues were found $8.67 \mathrm{ppb}, 7.18 \mathrm{ppb}$ and $0.81 \mathrm{ppb}$ accordingly. The highest mean concentration of Oxytetracycline (OTC) (10.15 ppb) was found in samples collected from local poultry sellers, whereas, the highest mean concentration of Tetracycline (TCL) (1.35 ppb) and Ciprofloxacin (CIP) (10.62 ppb) were observed in the samples obtained from local farm. The highest percentage of TCL and CIP (64\% and 48\% respectively) were found in samples collected from local farm. Chlortetracycline (CTC) was found predominant (70\%) in samples collected from Contract farms. On the other hand, out of 60 meat samples, $\mathrm{Cd}$ and $\mathrm{Cr}$ were detected in only one meat sample with concentration of $56.41 \mathrm{mg} / \mathrm{kg}$ and $14.44 \mathrm{mg} / \mathrm{kg}$ respectively. Lead was not detected in any of the meat samples.
\end{abstract}

Keywords: antibiotic residue; food safety; heavy metal; meat; poultry feed; public health; toxin

\section{Introduction}

Poultry is one of the fastest, easiest and cheapest sources of protein (meat and egg) for human consumption in Bangladesh and sometimes it's referred as poor man's animal protein. Adulteration of poultry meat and products 
is a serious public health concern which have detrimental effects for human life and health. Poultry meat and poultry feed can be contaminated by variety of contaminates (Sarker et al., 2020; Altherwi et al., 2018). Among them principle contaminants are heavy metals, antibiotics, metabolites, microorganisms, mycotoxins, hormones, polychlorinated biphenyls, genetically modified organisms, nitrates and nitrites, toxic pigments, pesticide residues, dioxins, , melamine and so one (Sarker et al., 2018; Hu et al., 2017).

Heavy metals are growing concern among principle contaminants of poultry meat, feed and other poultry products. Therefore, contamination of heavy metal in food and water is a major concern at national and international level due to food safety issues and human health risk through the food chain (Aktar et al., 2020; Yeasmin et al., 2017). Accumulations of heavy metals that occur through meat or other food materials eventually make their course into the body tissue (Islam et al., 2016; Baykov et al., 1996). The high degree toxicity of arsenic, cadmium, chromium, lead, and mercury has ranked them among the priority metals that are of public health significance. These are the systemic toxicants which cause multiple organ damage, even at lower levels of exposure. According to the U.S. Environmental Protection Agency, and the International Agency for Research on Cancer, these metallic elements are also identified as human carcinogenic agents (Tchounwou et al., 2012).

Antibiotics are the chemical agents which were formulated for saving the life of people and livestock from infections of bacteria (Hyung et al., 2017). The imprudent use of antibiotics both for prophylactic and therapeutic purposes has considered as global concern due to its residual effect, and subsequent adverse health hazards of consumers (Ferdous et al., 2019; Chanda et al., 2014). More importantly, in unauthorized veterinary practice, antibiotics are used illegally as growth promoter in the livestock and poultry instead of therapeutic (Altherwi et al., 2018; Talukder et al., 2017). Thus the wide spread use of antibiotics in poultry industry resulted in the presence of residuals in foodstuffs leading to a potential health hazards for consumers which include; carcinogenicity, mutagenicity, bone marrow toxicity, allergy (Paul et al., 2020; Nisha, 2008) as well as appearance of a resistant strains of pathogenic bacteria (Hussein and Khalil, 2013).

The poultry sub-sector of livestock sector is an essential part of fostering agricultural growth and reduces malnutrition for the people of Bangladesh (Hamid et al., 2017). It is an integral part of farming system in Bangladesh which created direct and indirect employment opportunity including support services near about six million people (Hamid et al., 2017; Raihan and Mahmud, 2008). Unfortunately, the research findings from Bangladesh showed presence of antibiotic residues and heavy metals in poultry feed, meat and eggs at public health concerning level (Bhuiyan et al., 2021, Bristy et al., 2019; Islam et al., 2019; Rashid et. al., 2018). Currently, the status of commonly used poultry feed quality ensuring standard nutrition values is very little known. Therefore, this research was undertaken to understand the current status of the presence of antibiotic residue (Tetracycline (TCL), Chlortetracycline (CTC), Oxytetracycline (OTC), Ciprofloxacin (CIP), Azithromycin (ATM)); heavy metals (Cadmium $(\mathrm{Cd})$, Chromium $(\mathrm{Cr})$, Lead $(\mathrm{Pb})$ and Arsenic $(\mathrm{As})$ ); and toxins (Aflatoxin) in poultry feed and meat for recommending implementable food safety measures in Bangladesh. However, CIP and ATM tested only for meat samples and CTC, As and aflatoxins tested only for feed samples.

\section{Materials and Methods}

\subsection{Study area}

The two poultry production belt districts of Bangladesh (Gazipur and Rajshahi) (Figure 1) were selected considering the number of poultry farms, number of hatcheries, and findings of previous field work of different organizations.

\subsection{Sampling design}

A cross-sectional study was carried out in the study areas in order to identify and quantify the presence of heavy metals, antibiotic residues, and toxin in broiler feed and meat. A total of 94 broiler feed samples and 60 broiler meat samples were collected and necessary subsets of the samples have been produced for laboratory investigation outlined in Table 1.

\subsubsection{Feed samples}

Among the 94 feed samples, 20 samples were collected from farm level which were prepared or mixed by farmer him/herself, 33 were from local and non-registered feed mills, and 41 were from the registered feed mills. Ready feed samples were collected from the retailer shops. Every sample $(500 \mathrm{gm})$ was collected aseptically for each of the subsets (3 subsets/sample), and placed into a sterile zipper-type plastic bag, and leveled with necessary information. To facilitate the absorption of additional moisture from feed, small silica gel packet was placed in each of the bag. A cautious approach was taken during the collection process of samples 
for Aflatoxin analysis to avoid moisture contamination. All the samples were transported in plastic box to the laboratory. All samples were stored in dry and cool place before analysis.
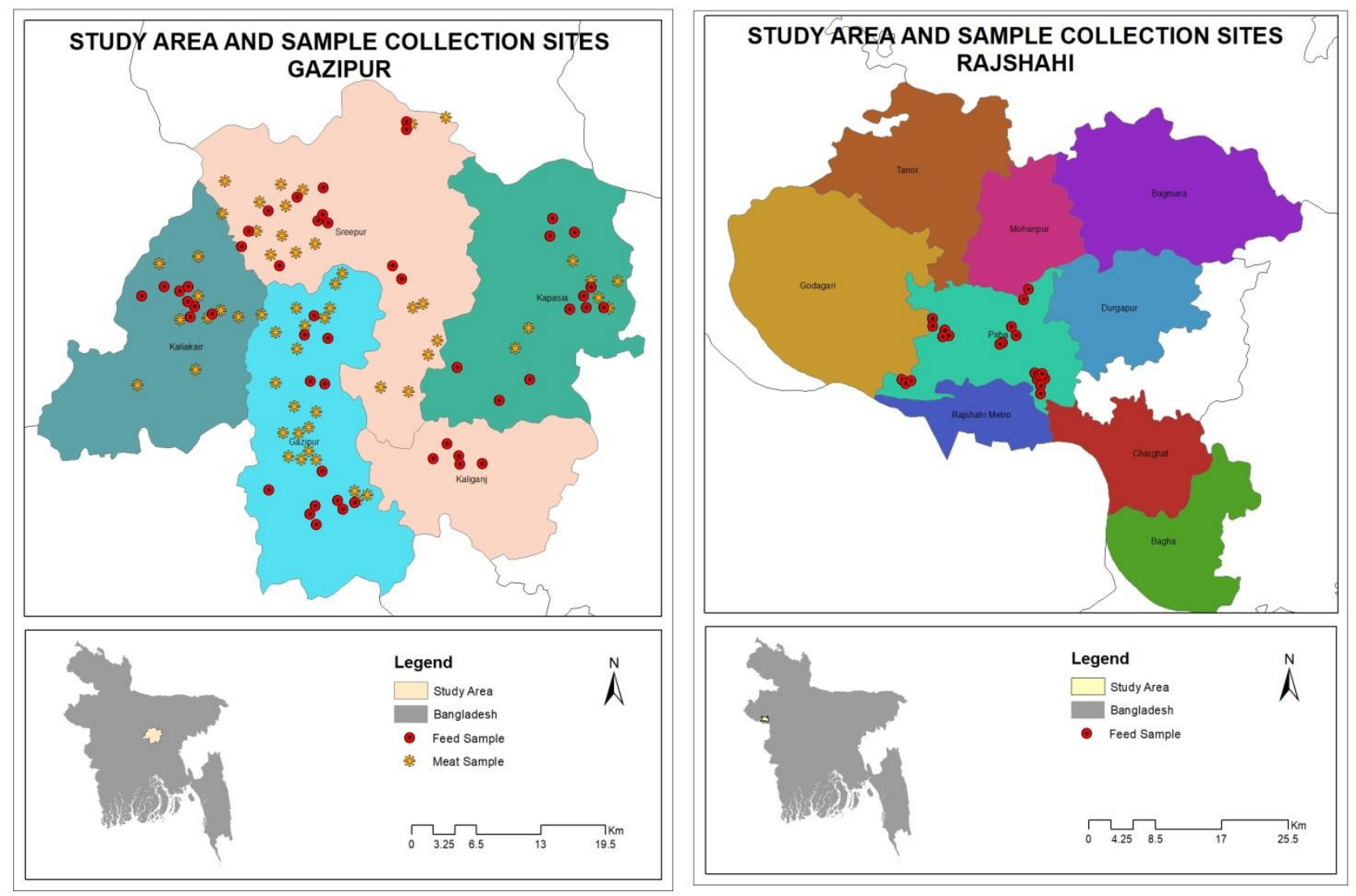

Figure 1. Study area maps of Gazipur and Rajshahi district based on Geographical Information System (GIS) created with ArcMap 10.7 software (ESRI, Redlands, California, USA).

\subsubsection{Meat samples}

Thigh and breast muscles of 5-6 weeks old broiler chicken were collected for this study. Out of 60 broiler meat samples, 10 were from contract farms, 25 from local broiler farms, and 25 from local poultry sellers. About $500 \mathrm{gm}$ of thigh and breast muscle was collected aseptically for each of the subsets (three subsets/sample), and leveled with necessary information. The sample was minced and mixed properly, and placed into a sterile zipper-type plastic bag. All the samples were transported in an icebox to the laboratory, and stored in $-20{ }^{\circ} \mathrm{C}$ freezer before analysis.

\subsection{Laboratory Test}

A capacity assessment was conducted by a Technical Advisory Committee and they provided necessary guidance to identify and select the laboratories to perform necessary laboratory investigations for this study. For the identification and quantification of antibiotic residue, Thin Layer Chromatography (TLC), High Performance Liquid Chromatography (HPLC) was used. To verify the result found through HPLC, same subset of the samples were also analyzed using Enzyme-linked Immunosorbent Assay (ELISA) technique.

The laboratory test techniques are outlined in Table 2. All the lab tests were performed by the laboratories following their own standardized and optimized protocols.

\section{Results and Discussion}

\subsection{Antibiotic residue in poultry feed}

A total of 90 feed samples were tested to identify and quantify the concentration of TCL, CTC, OTC residues. Overall, antibiotic residues were detected in $18.89 \%$ of the feed samples. Among them, OTC found predominant and was detected in $12.22 \%$ cases, whereas TCL found in $4.44 \%$ and CTC found in $2.22 \%$ samples (Table 3). Similar study conducted by Bangladesh Agricultural Research Council (BARC) and Patuakhali Science and 
Technology University (PSTU) and they found antibiotic residue in 50\% of the collected samples (Molla, 2019). It was also observed that the samples obtained from registered feed companies having the highest percentage of antibiotic residues these were $0.81 \%, 27.03 \%$ and $5.41 \%$ respectively for TCL, OTC and CTC. In addition to that, the concentrations of these antibiotics were $171.3 \mathrm{ppb}, 40 \mathrm{ppb}$ and $100.27 \mathrm{ppb}$ accordingly (not shown in table). Nonetheless, no antibiotic was detected in the sample obtained from non-registered or local feed companies.

Uncontrolled use of antibiotic growth promoter has been criticized by scientists, public health practitioners and food safety activists due to developing antibiotic resistance and treatment failure both in animal and human (Hyung et al., 2017). Studies found that antibiotic registrant gene can be transferred from animal to human pathogens. Also, it has public health significance for the possibility of horizontal transmission of Antibiotic Resistant Gene (ARG) in human and animal (Lerminiaux et al., 2019). To avoid the public health hazards, the Government of Bangladesh (GoB) prohibited the use of antibiotics in animal feed by establishing 'Fish Feed and Animal Feed Act 2010'.

\subsection{Antibiotic residue in poultry meat}

A total of 60 samples were collected to identify and quantify four different types of antibiotics (TCL, OTC, CIP and ATM). Overall screening result is showing that CIP residue ranked top and no ATM residues in the samples collected from all the three sources. Mean concentration of OTC was $8.67 \mathrm{ppb}$ whereas CIP, TCL and ATM were $7.18 \mathrm{ppb}, 0.81 \mathrm{ppb}$ and $0 \mathrm{ppb}$ consequently. In addition, the highest concentration of OCT, CIP, TCL and ATM were $152 \mathrm{ppb}, 88 \mathrm{ppb}, 20 \mathrm{ppb}$, and zero ppb respectively (Table 4). Importantly, OCT found as common antibiotic used in poultry farms. However, one good thing is that all the revealed antibiotic residual concentration were below Maximum Residue Limit (MRL) recommended by Food Safety (Contaminants, Toxins and Harmful Residues) Regulations, 2017 (Table 4).

The highest percentage of positive samples of antibiotic residue was found in samples of Local Farms (data not shown. Among them TCL was the highest and it was 64\%, whereas, CIP was found $48 \%$. In the case of contact farming, CIP was predominant in $70 \%$ meat samples (Table 5). On the other hand, the highest mean concentration $(10.15 \mathrm{ppb})$ of antibiotic residue found in samples collected from local poultry sellers and the antibiotic was OTC (Table 5).

Nonetheless, though all the revealed concentration of the antibiotic residues under below the MRL, still the findings of this research is a very good indication of widespread misuse of antibiotics in the farm level and live bird market. It also indicates lack of awareness among the poultry producers or disrespect to the regulations about the withdrawal periods of antibiotics in food animals and birds. Importantly, scientific evidence already proved that the unnecessary exposure of antibiotic even with a low dose for a long period has its drawbacks on consumer health and can lead to develop antibiotic resistance (Khan et al., 2015). Antimicrobial resistant bacteria in food animal can play serious consequence in human health system when they enter into the food (Founou et al., 2016).

\subsection{Heavy metal contamination in poultry feed}

There were 94 poultry feed samples was assessed for heavy metal contamination. Over all, all feed samples of all sources were positive for heavy metal contamination. The mean concentrations of $\mathrm{Cd}, \mathrm{Pb}$, and $\mathrm{Cr}$ were 0.04 $\mathrm{mg} / \mathrm{kg}, 1.28 \mathrm{mg} / \mathrm{kg}$ and $2.55 \mathrm{mg} / \mathrm{kg}$ respectively (Table 6). It was found that both the mean and highest concentrations of Cd were below the MRL $(0.5 \mathrm{mg} / \mathrm{kg})$ as prescribed by European Union in Opinion of the Scientific Committee on Animal Nutrition on Undesirable Substances in Feed, 2003. On the other hand, the mean concentration of $\mathrm{Pb}$ was also found below the MRL $(5 \mathrm{mg} / \mathrm{kg}$ ), whereas, the highest concentrated $\mathrm{Pb}$ positive sample was around three times higher $(14.65 \mathrm{mg} / \mathrm{kg}$ ) than the MRL (Table 6). However, earlier studies in Bangladesh found up to $30.27 \mathrm{ppm}$ lead in their analyzed poultry feed samples (Rashid et al., 2018). In addition, the highest mean concentration of $\mathrm{Cd}(0.054 \mathrm{mg} / \mathrm{kg})$ and $\mathrm{Pb}(2.48 \mathrm{mg} / \mathrm{kg})$ found in the feed samples collected from Non Registered Companies. In contrast, the highest concentration (2.78) of Cr found in the samples obtained from Registered Companies (Table 7).

According to European Union (EU, 2003), there are no maximum allowed concentrations of Cr for poultry feed. In this study, chromium was detected in all feed samples. However, the MRL for $\mathrm{Cr}$ concentrations in human food lies between 0.1 and $0.5 \mathrm{mg} / \mathrm{kg}$ (Alkhalaf et al., 2010). The major source of $\mathrm{Cr}$ in poultry feed samples could be from tannery solid waste and its effluent (Tariq, 2009). Accumulation of $\mathrm{Pb}$ in human body might be occurred from animal and poultry feed. As non-essential nutrients, $\mathrm{Cd}$ and $\mathrm{Pb}$ have no or very limited requirement to human and livestock health, and may accumulate in the body, particularly in the kidney, liver, and to a lesser extent in the muscle ( $\mathrm{Li}$ et al., 2005). Musculo-skeletal, renal, ocular, neurological, 
immunological, reproductive and developmental disorders are common outcomes of $\mathrm{Pb}$ toxicity in human and animal health (Ambedkar and Muniyan, 2012). In spite of the evidence of carcinogenic potency of $\mathrm{Cd}$ in experimental animals, its carcinogenicity in humans is not well defined (Costa, 2000). However, Cd has been classified as 'Group I' human carcinogen by 'International Agency for Research on Cancer (IARC, 1993). The effects of acute cadmium poisoning in humans are very serious. Among them are high blood pressure, kidney damage, destruction of testicular tissue, and destruction of red blood cells (Altherwi et al., 2018).

\subsection{Heavy metal contamination in poultry meat}

Among the tested 60 poultry meat samples, there was only one sample found positive for $\mathrm{Cd}$ and $\mathrm{Cr}$ and concentration were $56.41 \mathrm{mg} / \mathrm{kg}$ and $14.44 \mathrm{mg} / \mathrm{kg}$ respectively. Moreover, $\mathrm{Pb}$ was not detected in any of the meat samples.

\subsection{Aflatoxin in poultry feed}

Aflatoxins are classified as poisonous carcinogens that are produced by certain fungi which grow in agricultural crops, decaying vegetation, hay, and grains. Quality of feed and feed ingredients can be affected by the presence of Aflatoxin, and this can subsequently create health hazards to animals and humans. In this study, a total of 50 feed samples were tested to identify and quantify Aflatoxin (B1, B2, G1, G2) using HPLC with fluorescence detector. The detection limit was $0.5 \mu \mathrm{g} / \mathrm{kg}$. However, Aflatoxin was not detected in any of the feed samples. This indicates the good stranded of manufacturing and storing practice of feed ingredients by the commercial poultry feed producer.

Table 1. Subset of samples for laboratory analysis of heavy metal, antibiotic residue and toxin.

\begin{tabular}{|l|c|l|l|}
\hline \multirow{2}{*}{ Lab investigation } & \multicolumn{2}{|c|}{ Subset of the samples } & \multirow{2}{*}{ Total } \\
\cline { 2 - 4 } & Meat & Feed & 154 \\
\hline Heavy metal & 60 & 94 & 50 \\
\hline Toxin (Aflatoxin) & 0 & 50 & 210 \\
\hline Antibiotic residue & 120 & 90 & $\mathbf{4 1 4}$ \\
\hline Total & $\mathbf{1 8 0}$ & $\mathbf{2 3 4}$ & \\
\hline
\end{tabular}

Table 2. Laboratory tests and associated methods.

\begin{tabular}{|c|c|c|c|c|}
\hline $\begin{array}{l}\text { Type of } \\
\text { Sample }\end{array}$ & Name of the Test & $\begin{array}{l}\text { Name of the Laboratory } \\
\text { and Country }\end{array}$ & Method & $\begin{array}{l}\text { Number of the } \\
\text { Sample Subset }\end{array}$ \\
\hline \multirow{2}{*}{ Meat } & $\begin{array}{l}\text { Antibiotic residue test (TCL, } \\
\text { OCT, CIP, ATM) }\end{array}$ & $\begin{array}{l}\text { BAU*, Mymensignh, } \\
\text { Bangladesh }\end{array}$ & $\begin{array}{l}\text { TLC, HPLC and } \\
\text { ELISA }\end{array}$ & 60 \\
\hline & $\begin{array}{l}\text { Heavy metal test }(\mathrm{Cd}, \mathrm{Cr} \text {, } \\
\mathrm{Pb})\end{array}$ & SGS*, India & $\begin{array}{l}\text { S0-IN-MUL-TE-063 } \\
\text { by ICP-MS }\end{array}$ & 60 \\
\hline \multirow{3}{*}{ Feed } & $\begin{array}{l}\text { Antibiotic residue test (TCL, } \\
\text { CTC, OCT) }\end{array}$ & BCSIR*, Bangladesh & HPLC-FLD & 92 \\
\hline & $\begin{array}{l}\text { Heavy metal test }(\mathrm{Cd}, \mathrm{Cr} \text {, } \\
\mathrm{Pb})\end{array}$ & SGS*, India & $\begin{array}{l}\text { AOAC-ICP- } \\
\text { OES/MS }\end{array}$ & 94 \\
\hline & Toxin test (Aflatoxin) & BCSIR*, Bangladesh & HPLC-FLD & 50 \\
\hline
\end{tabular}

*BAU, Bangladesh Agricultural University; SGS, Standard Global Services; BCSIR, Bangladesh Council of Scientific and Industrial Research 
Table 3. Percentages of positive feed samples having antibiotic residues using HPLC-FLD.

\begin{tabular}{|l|l|l|l|l|}
\hline \multirow{2}{*}{ Source of Samples } & \multicolumn{4}{|c|}{ Positive feed samples for antibiotic residues } \\
\cline { 2 - 5 } & TCL & OTC & CTC & Total Positive \\
\cline { 2 - 5 } & $\mathbf{n}(\mathbf{\%})$ & $\mathbf{n}(\mathbf{\%})$ & $\mathbf{n}(\mathbf{\%})$ & $\mathbf{n}(\mathbf{\%})$ \\
\hline Registered Companies (n=37) & $4(10.81)$ & $10(27.03)$ & $2(5.41)$ & $\mathbf{1 6}(\mathbf{4 3 . 2 5})$ \\
\hline $\begin{array}{l}\text { Non Registered Companies/Local poultry feed mills } \\
(\mathrm{n}=33)\end{array}$ & $0(0.00)$ & $0(0.00)$ & $0(0.00)$ & $\mathbf{0 ( 0 . 0 0 )}$ \\
\hline Farmer Produced Feed (n=20) & $0(0.00)$ & $1(5.00)$ & $0(0.00)$ & $\mathbf{1 ( 5 . 0 0 )}$ \\
\hline Total (N=90) & $\mathbf{4 ( 4 . 4 4 )}$ & $\mathbf{1 1 ( 1 2 . 2 2 )}$ & $\mathbf{2 ( \mathbf { 2 . 2 2 } )}$ & $\mathbf{1 7 ( 1 8 . 8 9 )}$ \\
\hline
\end{tabular}

TCL-Tetracycline; OTC- Oxy-tetracycline and CTC- Chlortetracycline

Table 4. Positive sample percentages and concentrations of antibiotic residue in poultry meat samples by HPLC (N=60).

\begin{tabular}{|l|l|l|l|l|l|}
\hline HPLC & $\begin{array}{l}\text { Positive } \\
\text { Sample } \\
(\mathbf{\%})\end{array}$ & $\begin{array}{l}\text { Lowest } \\
\mathbf{C o n c e n t r a t i o n} \\
(\mathbf{p p b})\end{array}$ & $\begin{array}{l}\text { Highest } \\
\text { Concentration } \\
(\mathbf{p p b})\end{array}$ & Mean $(\mathbf{p p b})$ & $\begin{array}{l}\text { MRL } \\
(\mathbf{p p b})\end{array}$ \\
\hline Tetracycline (TCL) & 43.33 & 0 & 20 & 0.81 & 200 \\
\hline Oxytetracycline (OTC) & 33.33 & 0 & 152 & 8.67 & 200 \\
\hline Ciprofloxacin (CIP) & 50 & 0 & 88 & 7.18 & 100 \\
\hline Azythromycin (ATM) & 0 & 0 & 0 & 0 & 0 \\
\hline
\end{tabular}

*MRL, Maximal Residue Limit

${ }^{1}$ Food Safety (Contaminants, Toxins and Harmful Residues) Regulations, 2017

Table 5. Percentages and concentration of positive poultry meat samples having antibiotic residues using HPLC-FLD.

\begin{tabular}{|c|c|c|c|c|c|c|c|c|}
\hline \multirow{3}{*}{\begin{tabular}{|l|} 
Source of Samples \\
$(\mathbf{N}=60)$
\end{tabular}} & \multicolumn{8}{|c|}{ Positive feed samples for antibiotic residues } \\
\hline & \multicolumn{2}{|c|}{ TCL } & \multicolumn{2}{|c|}{ OTC } & \multicolumn{2}{|c|}{ CTC } & \multicolumn{2}{|c|}{ ATM } \\
\hline & $\%$ & Mean (ppb) & $\%$ & Mean (ppb) & $\%$ & Mean (ppb) & $\%$ & Mean (ppb) \\
\hline Contract Farm $(\mathrm{n}=10)$ & 0 & 0 & 10 & 5.47 & 70 & 8.91 & 0 & 0 \\
\hline Local Farm ( $\mathrm{n}=25)$ & 64 & 1.35 & 48 & 8.46 & 52 & 10.62 & 0 & 0 \\
\hline Local Poultry Seller $(n=25)$ & 40 & 0.58 & 28 & 10.15 & 40 & 2.76 & 0 & 0 \\
\hline
\end{tabular}

TCL, Tetracycline; OTC, Oxy-tetracycline and CTC, Chlortetracycline; ATM, Azithromycin

Table 6. Concentrations of $\mathrm{Cd}, \mathrm{Pb}$ and $\mathrm{Cr}$ in poultry feed samples.

\begin{tabular}{|l|l|l|l|l|l|}
\hline Heavy Metals & $\begin{array}{l}\text { Positive Sample } \\
\mathbf{( \% )}\end{array}$ & $\begin{array}{l}\text { Lowest } \\
\text { Concentration } \\
\mathbf{( m g / k g})\end{array}$ & $\begin{array}{l}\text { Highest } \\
\text { Concentration } \\
(\mathbf{m g} / \mathbf{k g})\end{array}$ & $\begin{array}{l}\text { Mean } \\
(\mathbf{m g} / \mathbf{k g})\end{array}$ & $\mathbf{M R L}^{\mathbf{2}}(\mathbf{m g} / \mathbf{k g})$ \\
\hline Cadmium $(\mathbf{C d})$ & 100 & 0.01 & 0.21 & 0.04 & 0.50 \\
\hline Lead $(\mathbf{P b})$ & 100 & 0.03 & 14.65 & 1.28 & 5.00 \\
\hline Chromium $(\mathbf{C r})$ & 100 & 0.05 & 49.22 & 2.55 & 0.00 \\
\hline
\end{tabular}

${ }^{2}$ European Union, Opinion of the Scientific Committee on Animal Nutrition on Undesirable Substances in Feed, 2003 
Table 7. Concentrations of $\mathrm{Cd}, \mathrm{Pb}$, and $\mathrm{Cr}$ in poultry feed samples obtained from different sources.

\begin{tabular}{|l|l|l|l|l|l|l|}
\hline \multirow{2}{*}{ Source of Feed Samples } & \multicolumn{2}{|c|}{ Cd } & \multicolumn{2}{c|}{ Pb } & \multicolumn{2}{c|}{ Cr } \\
\cline { 2 - 8 } & $\begin{array}{l}\text { Positive } \\
\text { Sample } \\
(\boldsymbol{\%})\end{array}$ & $\begin{array}{l}\text { Mean } \\
(\mathbf{m g} / \mathbf{k g})\end{array}$ & $\begin{array}{l}\text { Positive } \\
\text { Sample } \\
(\boldsymbol{\%})\end{array}$ & $\begin{array}{l}\text { Mean } \\
(\mathbf{m g} / \mathbf{k g})\end{array}$ & $\begin{array}{l}\text { Positive } \\
\text { Sample } \\
(\boldsymbol{\%})\end{array}$ & $\begin{array}{l}\text { Mean } \\
(\mathbf{m g} / \mathbf{k g})\end{array}$ \\
\hline Registered Feed Companies (n=41) & 100 & 0.033 & 100 & 0.46 & 100 & 2.78 \\
\hline $\begin{array}{l}\text { Non Registered Feed Companies/Local } \\
\text { poultry feed mills (n=33) }\end{array}$ & 100 & 0.053 & 100 & 2.47 & 100 & 2.61 \\
\hline Farmer Produced (n=20) & 100 & 0.05 & 100 & 0.99 & 100 & 2.16 \\
\hline
\end{tabular}

\section{Conclusions}

In this study found that only $18.89 \%$ collected poultry feed sample had antibiotic residues which were below the MRL and majority of the positive samples sourced from commercial poultry feed. However, only presence of residues is more than enough for public health concern and increased AMR risk. According to the Govt. law of Bangladesh, indiscriminate use of antibiotics in commercial poultry feed production is very unethical, illegal and punishable crime. In addition, this study also revealed that the mean concentration of heavy metals $(\mathrm{Cd}$ and Cr) below the MRL except Pd. There were 6\% feed samples had Pd which exceeded MRL and it can be hazardous both for animal and human health. Therefore, this study recommended for the proper maintenance of the antibiotic withdrawal period, increased food safety concern of the civil society and come forward activities of the government to mitigate the food safety challenges.

\section{Acknowledgments}

The authors would like to thanks for the support of the Promoting Knowledge for Accountable Systems (PROKAS) programme of British Council for their support to conduct this study.

\section{Conflict of interest}

None to declare.

\section{Authors' contribution}

A Atiq Rahman and Dwijendra Lal Mallick planned and deigned the study. Eftesum helped in the collection of samples. Farhana Rahman prepared the map of the study areas. Md Mahbubul Alam and S. M. Lutful Kabir were involved to analyze the samples in the laboratory. Md Murshidul Ahsan wrote the manuscript. AHM Taslima Akhter and S. M. Lutful Kabir finalized the manuscript. All authors have read and approved the final manuscript.

\section{References}

Aktar S, YA Sarker, S Sachi, J Ferdous, ZA Noman, KM Mohiuddin and MH Sikder, 2020. Environmental contamination of lead in dairy farms in Narayangonj, Bangladesh. J. Adv. Vet. Anim. Res., 7: 621-625.

Alkhalaf NA, AK Osman and KA Salama, 2010. Monitoring of aflatoxins and heavy metals in some poultry feeds. African J. Food Sci., 4: 192-199.

Altherwi EM, YM Soliman and FK Khalifa, 2018. Detection of heavy metals and antibiotic compounds in some local and export meats. Int. J. Adv. Res. Biol. Sci., 5: 114-121.

Ambedkar G and M Muniyan, 2012. Analysis of heavy metals in water, sediments and selected freshwater fish collected from gadilam river, Tamilnadu, India. Int. J. Toxicol. Appl. Pharmacol., 2: 25-30.

Bhuiyan MMI, MS Islam, MR Hasan and Islam KR, 2021. Thin layer chromatographic detection of enrofloxacin antibiotic residues in poultry tissue. Asian Australas. J. Food Saf. Secur., 5: 11-18.

Bristy NI, S Das, ZA Noman, J Ferdous, S Sachi, SML Kabir and MH Sikder, 2019. Colistin residue in broiler: detection in different growth stages. Asian Australas. J. Food Saf. Secur., 3: 43-47.

Chanda R, R Fincham and P Venter, 2014. Review of the Regulation of Veterinary Drugs and Residues in South Africa. Crit. Rev. Food Sci .Nutr., 54: 488-494.

Costa M, 2000. Trace elements: aluminum, arsenic, cadmium, and nickel. In Morton Lippmann (ed.) Environmental Toxicants: Human Exposures and Their Health Effects, 2/e. John Wiley and Sons, Inc. pp. 811-850.

EU, 2003. Opinion of the Scientific Committee on Animal Nutrition on Undesirable Substances in Feed, Health and Consumer Protection Directorate-General, European Union, Belgium. 
Ferdous J, S Sachi, ZA Noman, SMAK Hussani, YA Sarker and MH Sikder, 2019. Assessing farmers' perspective on antibiotic usage and management practices in small-scale layer farms of Mymensingh district, Bangladesh. Vet. World, 12: 1441-1447.

Founou LL, RC Founou and SY Essack, 2016. Antibiotic Resistance in the Food Chain: A Developing CountryPerspective. Front Microbiol., 7: 1881.

Hamid MA, MA Rahman, S Ahmed and KM Hossain, 2017. Status of Poultry Industry in Bangladesh and the Role of Private Sector for its Development. Asian J. Poult. Sci., 11: 1-13.

Hu B, X Jia, J Hu, D Xu, F Xia and Y Li, 2017. Assessment of heavy metal pollution and health risks in the soil-plant-human system in the Yangtze River delta, China. I. J. Environ. Res. Public Health, 14: 1042.

Hussein MA and S Khalil, 2013. Screening of some antibiotics and anabolic steroids residues in broiler breast marketed in El-Sharkia governorate. Life Sci. J., 10: 2111-2118.

Hyung SW, CH Lee and B Kim, 2017. Development of certified reference materials for accurate determination of fluoroquinolone antibiotics in chicken meat. Food Chem., 229: 472-478.

IARC, 1993. IARC Cadmium and Cadmium Compounds: Monographs on the Evaluation of Carcinogenic Risks to Humans. Lyon: International Agency for Research on Cancer. vol. 58, pp. 119-237.

Islam MM, SML Kabir, YA Sarker, MH Sikder, SKS Islam, AHMT Akhter and MM Hossain, 2016. Risk assessment of chromium levels in broiler feeds and meats from selected farms of Bangladesh. Bangladesh J. Vet. Med., 14: 131-134.

Islam MS, MZ Islam and MS Islam, 2019. Discriminate and indiscriminate use of amoxicillin antibiotic and detection of its residue in poultry edible tissue by thin layer chromatography (TLC) method. Asian Australas. J. Food Saf. Secur., 3: 96-102.

Khan GJ, RA Khan, I Majeed, FA Siddiqui and S Khan, 2015. Ciprofloxacin; the frequent use in poultry and its consequences on human health. Prof. Med. J., 22: 001-005.

Lerminiaux NA and ADS Cameron, 2019. Horizontal transfer of antibiotic resistance genes in clinical environments. Can. J. Microbiol. 65: 34-44.

Li Y, DF McCory, JM Powell, H Saam and D Jackson-Smith, 2005. A survey of selected heavy metal concentrations in Wisconsin dairy feeds. J. Dairy Sci., 88: 2911-2922.

Molla MA, 2019. Poultry feed laced with antibiotics. The Daily Star, 13 April. pp. 1.

Nisha AR, 2008. Antibiotic Residues - A Global Health Hazard. Vet. World, 1: 375-377.

Paul TK, MM Hasan, MA Haque, S Talukder, YA Sarker, MH Sikder, MAHNA Khan, MN Sakib and A Kumar, 2020. Dietary supplementation of Neem (Azadirachta indica) leaf extracts improved growth performance and reduced production cost in broilers. Vet. World, 13: 1050-1055.

Raihan S and N Mahmud, 2008. Trade and Poverty Linkages: A Case Study of the Poultry Industry in Bangladesh, Cuts Citee Working Paper No.6.

Rashid MA, MSK Sarker, H Khatun, NR Sarker, MY Ali and MN Islam, 2018. Detection of heavy metals in poultry feed, meat and eggs. Asian Australas. J. Food Saf. Secur., 2: 1-5.

Sarker YA, MM Hasan, TK Paul, SZ Rashid, MN Alam and MH Sikder, 2018. Screening of antibiotic residues in chicken meat in Bangladesh by thin layer chromatography. J. Adv. Vet. Anim. Res., 5: 140-145.

Sarker YA, SZ Rashid, S Sachi, J Ferdous, BL Das Chowdhury, SS Tarannum and MH Sikder, 2020. Exposure pathways and ecological risk assessment of common veterinary antibiotics in the environment through poultry litter in Bangladesh. J. Environ. Sci. Health B, 55: 1061-1068.

Talukder S, MM Hasan, ZA Noman, YA Sarker, TK Paul and MH Sikder, 2017. Effect of dietary supplementation of ginger extract on growth, carcass characteristics and haematological parameters in broilers. Asian J. Med. Biol. Res., 3: 211-215.

Tariq SR, 2009. Correlation studies on the trace metals levels in effluents in relation to soil and water in proximity of tanneries. PhD Thesis, Quaid-e-Azam University, Pakistan, pp. 6-10.

Tchounwou PB, CG Yedjou, AK Patlolla and Sutton DJ, 2012. Heavy metal toxicity and the environment. Experientia supplementum, 101: 133-164.

Yeasmin N, S Ali, S Hossain, A Hossain, KN Sharmin and A Begum, 2017. Assessment of heavy metal concentration in poultry meat samples collected from Chittagong city. IJCMS, 3: 710-714. 